\title{
Optimalisasi Penentuan Lurah Berprestasi Se-Kecamatan Bogor Timur Kota Bogor dengan Menggunakan Metode Decission Tree
}

\author{
Oleh : Siti Maisyaroh
}

\begin{abstract}
Abstrak
Kecamatan Bogor Timur Kota Bogor terdiri dari 6 Kelurahan yang masing - masing dipimpin oleh seorang Lurah. Kepemimpinan lurah dalam meminpin wilayah nya yang semakin maju dan berkembang perlu adanya apresiasi atas jasa Lurah. Oleh karena itu diperlukan proses Pemilihan Lurah berprestasi agar Lurah dapat lebih termotivasi dalam menjalankan tugas. Untuk lebih optimal dalam proses penentuan Lurah Berprestasi diperlukan metode yang tepat, oleh karena metode Simple Additive Weighting (SAW) dapat lebih mengoptimalkan proses perhitungan karena proses perhitungan dilakukan dengan penjumlahan berbobot. Perhitungan dimulai dari menentukan kriteria, menentukan rating kecocokan setiap alternatif pada setiap kriteria, membuat matriks keputusan berdasarkan kriteria, kemudian melakukan normalisasi matriks berdasarkan persamaan yang disesuaikan dengan jenis atribut sehingga diperoleh matriks ternormalisasi $R$. Kemudian hasil akhir diperoleh dari matriks ternormalisasi $R$ dengan vector bobot sehingga diperoleh nilai terbesar yang dipilih sebagai alternatif terbaik sebagai solusi. Kriteria dan bobot penilaian didapat dari hasil wawancara dari bagian Kepegawaian Kecamatan Bogor Timur Kota Bogor. Setelah dilakukan proses perhitungan dengan metode Simple Additive Weighting (SAW) diperoleh hasil yaitu Lurah Katulampa dengan nilai 0,95, dilanjutkan dengan Lurah Sindangrasa dengan nilai 0,93, Lurah Tajur dengan nilai 0,91, Lurah Baranangsiang dengan nilai 0,87, Lurah Sindangsari dengan nilai 0,86 dan yang terakhir Lurah Sukasari dengan nilai 0,80. Dengan demikian Metode Simple Additive Weighting (SAW) dapat digunakan untuk optimalisasi dalam menentukan Lurah Berprestasi seKecamatan Bogor Timur Kota Bogor dengan tingkat akurasi sebesar 0,83\%

Kata Kunci : Data Mining, Algoritma C4.5, Decission Tree
\end{abstract}

\section{Pendahuluan}

Instansi pemerintah daerah Kota dan Kabupaten salah satunya terdiri dari Satuan Kerja Perangkat Daerah (SKPD) yang meliputi Kecamatan dan Kelurahan.Kecamatan adalah pembagian wilayah administratif di Indonesia di bawah Kabupaten atau Kota. Kecamatan atau sebutan lain adalah wilayah kerja Camat sebagai perangkat daerah kabupaten atau kota (PP.19 tahun 2008). Kedudukan kecamatan merupakan perangkat daerah kabupaten atau kota sebagai pelaksana teknis kewilayahan yang mempunyai wilayah kerja tertentu dan dipimpin oleh Camat dan pemimpin dari kelurahan - kelurahan.

Kelurahan menurut Peraturan Pemerintah Nomor 73 Tahun 2005 tentang Kelurahan. Kelurahan adalah wilayah kerja Lurah sebagai perangkat daerah kabupaten ataukota dalam wilayah kecamatan. Kelurahan merupakan instasi pemerintah kota atau kabupaten terkecil setingkat Desa yang dipimpin oleh seorang Lurah yang berstatus sebagai Pegawai Negeri Sipil (PNS). Pemerintah Kota Bogor memiliki 6 Kecamatan yang tediri dari 68 Kelurahan. Salah satu Kecamatan yang ada di Kota Bogor adalah Kecamatan Bogor Timur yang terdiri dari 6 Kelurahan yaitu Kelurahan Baranangsiang, Kelurahan Sukasari, Kelurahan Katulampa, Kelurahan Tajur, Kelurahan Sindangrasa dan Kelurahan Sindangsari. Kelurahan dibentuk untuk meningkatkan pelayanan masyarakat, melaksanakan fungsi pemerintahan dan pemberdayaan masyarakat dalam rangka mempercepat terwujudnya kesejahteraan masyarakat, maka dari itu perlu adanya pemimpin Kelurahan (Lurah) yang mempunyai loyalitas tinggi demi terciptanya 
Kelurahan yang lebih maju. Lurah mempunyai peranan penting dalam kemajuan wilayahnya. Dalam pelaksanaannya untuk memberikan apresiasi kepada para Lurah berprestasi perlu adanya pemberian penghargaan atas jasa Lurah dalam bidang cipta, karsa dan karya yang bermanfaat bagi wilayah dan masyarakatnya.

Penilaian Lurah berprestasi dilakukan oleh camat Bogor Timur dengan data - data yang ada di bagian kepegawaian Kecamatan Bogor Timur. Dalam penilaian Lurah berprestasi di Kecamatan Bogor Timur ini biasanya masih menggunakan sistem manual dimana proses pemilihan hanya dilakukan dari segi subjektifitas saja, selain itu penilaian hanya dilakukan berdasarkan penilaian Camat Bogor Timur. Sistem penilaiannya yang masih menggunakan sistem manual tentunya hasil dari yang didapat dari penilaian tersebut belum optimal. Oleh karena itu diperlukan penerapan metode Decision Tree (Decision 3) untuk mengoptimalkan penentuan Lurah Berprestasi se- Kecamatan Bogor Timur Kota Bogor. Hal ini bertujuan agar proses dan hasil penilaian agar lebih tepat sasaran sesuai hasil perhitungan dan untuk menghindari kecurangan serta hal-hal yang tidak diinginkan.

Untuk membantu melakukan penilaian dalam menentukan Lurah berprestasi agar lebih optimal pengambilan keputusan yang tepat adalah dengan menerapkan metode Decision Tree (Decision 3). Decision Tree (Decision 3) adalah suatu metode yang merupakan salah satu metode klasifikasi yang menggunakan representasi struktur pohon (tree) di mana setiap node merepresentasikan atribut, cabangnya merepresentasikan nilai dari atribut, dan daun merepresentasikan kelas.

Metode Decision Tree (Decision 3) ini merupakan salah satu metode dari Decission Support System (DSS) yang bisa digunakan dalam mambantu untuk menentukan lurah berprestasi karena akan menghasilkan suatu keputusan, dimana proses perhitungan dihitung berdasarkan dari kriteria - kriteria yang ada dan akan dimasukan kedalam metode Decision Tree (Decision 3)) untuk dihitung.

Metode ini dipilih karena mampu menyeleksi alternatif terbaik dari sejumlah alternatif berdasarkan kriteria - kriteria yang ditentukan. Kriteria dalam penilaian Lurah berprestasi ini adalah SKP (Sasaran Kerja Pegawai) yang terdiri dari indikator kuantitas, kualitas, waktu dan biaya, Prilaku kerja yang terdiri dari indikator integritas, komitmen, disiplin, kerjasama dan kepemimpinan, selanjutnya Kreativitas dan Inovasi, indikator nya adalah dengan pencapaian program lurah seperti peraihan PBB, memenangkan perlombangan tingkat Kota maupun Provinsi, dalam pengentasan kemiskinan dan dalam menurunkan angka pengangguran di wilayahnya masing - masing dan kriteria yang terakhir adalah Orientasi Pelayanan, orientasi pelayanan ini adalah dengan melakukan pelayanan yang baik terhadap warga, serta adanya kontribusi dan timbal balik antara Lurah dan warga masyarakat. Setelah ditentukan kriteria kemudian dilakukan proses perangkingan yang akan menentukan Lurah Berprestasi yang direkomendasikan.

\section{Permasalahan Penelitian}


Untuk mengapresiasikan atas pencapaian program - program yang telah dicapai perlu adanya penghargaan atas Lurah berprestasi. Di Kecamatan Bogor Timur penilaian atas peran Lurah ini dimaksud untuk memberikan apresiasi atas pencapaian program yang ditelah dicapai.Namun kenyataan yang ada pada Kecamatan Bogor Timur, penilaian Lurah masih menggunakan sistem manual dan hanya dari segi subjektifitas saja. Padahal jika tidak didasarkan pada kriteria yang ada hasil yang didapat tidak optimal. Penilaian yang tidak optimal dapat menjadikan kecemburuan sosial antara Lurah se-Kecamatan Bogor Timur Kota Bogor, selain itu dapat menurunkan semangat dalam mencapai program kerja. Berdasarkan uraian diatas maka dapat diidentifikasi masalah :

1. Sulit untuk menentukan bobot penilaian Lurah berprestasi se-Kecamatan Bogor Timur Kota Bogor

2. Sulit untuk menentukan alternatif pilihan Lurah berprestasi se-Kecamatan Bogor Timur Kota Bogor.

\section{Tujuan dan Manfaat Penelitian}

Adapun tujuan dari penilitian ini adalah :

1. Untuk menentukan bobot penilaian Lurah berprestasi se-Kecamatan Bogor Timur Kota Bogor.

2. Untuk menentukan alternatif pilihan Lurah berprestasi se-Kecamatan Bogor Timur Kota Bogor.

\section{Landasan Teori}

\section{Sistem Pendukung Keputusan}

Sistem pendukung keputusan (SPK) menurut Sri Kusumadewi (2006) adalah bagian dari sistem informasi berbasis komputer termasuk sistem berbasis pengetahuan atau manajemen pengetahuan yang dipakai untuk mendukung pengambilan keputusan dalam suatu organisasi atau perusahaan. Dapat juga dikatakan sebagai sistem komputer yang mengolah data menjadi informasi untuk mengambil keputusan dari masalah semi terstruktur yang spesifik.

\section{Data Mining}

Data mining adalah campuran dari statistic, kecerdasan buatan, dan riset data yang masih berkembang. (Gorunescu, 2011)

Data mining dibagi menjadi beberapa kelompok berdasarkan tugas yang dapat dilakukan, yaitu :

1. Deskripsi

Terkadang peneliti dan analis secara sederhana ingin mencoba mencari cara untuk menggambarkan pola dan kecenderungan yang terdapat dalam data. Sebagai contoh, petugas pengumpulan suara mungkin tidak dapat menemukan keterangan atau fakta 
bahwa siapa yang tidak vukup profesional akan sedikit didukung dalam pemilihan presiden. Deskripsi dari pola dan kecenderungan sering memberikan kemungkinan penjelasan untuk suatu pola atau kecenderungan.

2. Estimasi

Estimasi hampir sama dengan klasifikasi, kecuali variabel target estimasi lebih ke arah numerik daripada ke arah kategori. Model dibangun menggunakan record lengkap yang menyediakan nilai dari variabel target sebagai nilai prediksi. Selanjutnya, pada penilaian berikutnya estimasi nilai dari variabel target dibuat berdasarkan nilai variabel prediksi. Sebagai contoh, akan dilakukan estimasi tekanan darah sistolik pada pasien rumah sakit berdasarkan umur pasien, jenis kelamin, indeks berat badan, dan level sodium darah. Hubungan antara tekanan darah sistolik dan nilai variabel prediksi dalam proses pembelajaran akan menghasilkan model esrimasi. Model estimasi yang dihasilkan dapat digunakan untuk kasus baru lainnya.

3. Prediksi

Prediksi hampir sama dengan klasifikasi dan estimasi, kecuali dalam prediksi nilai dari hasil akan ada di masa mendatang.

4. Klasifikasi

Di dalam klasifikasi terdapat target variabel kategori. Sebagai contoh penggolongan pendapatan dapat dipisahkan dalam tiga kategori, yaotu pendapatan tinggi, pendapatan sedang, pendapatan rendah. Kemudian untuk menentukan pendapatan seorang pegawai, dipakai cara klasifikasi dalam data mining

5. Pengklusteran

Pengklusteran merupakan pengelompokkan record, pengamatan atau memperhatikan dan membentuk kelas objek-objek yang mempunyai kemiripan. Kluster adalah kumpulan record yang memiliki kemiripan satu dengan yang lainnya dan memiliki ketidakmiripan dengan record-record dalam kluster lain.

6. Asosiasi

Tugas asosiasi dalam data mining adalah menemukan atribut yang muncul dalam satu waktu. Dalam dunia bisnis lebih umum disebut analisis keranjang belanja. Asosiasi mencari kombinasi jenis barang yang akan terjual untuk bulan depan.

\section{Decision Tree}

Menurut Eko Prasetyo (2014) Decision Tree atau pohon keputusan adalah pohon yang digunakan sebagai prosedur penalaran untuk mendapatkan jawaban dari masalah yang dmasukkan.

Decision Tree atau pohon keputusan adalah pohon yang digunakan sebagai prosedur penalaran untuk mendapatkan jawaban dari masalah yang dimasukkan.Pohon yang dibentuk tiak selalu berupa pohon biner. Jika semua fitur dalam data set menggunakan 2 macam nilai 
kategorikal maka bentuk pohon yang didapatkan berupa pohon biner. Jika dalam fitur berisi lebih dari 2 macam nilai kategorikal atau menggunakan tipe numerik maka bentuk pohon yang didapatkan biasanya tidak berupa pohon biner (Preseyo Eko, 2014)

Kefleksibelan membuat metode ini aktraktif, khususnya karena memberikan keuntungan berupa visualisasi saran (dalam bentuk decision tree) yang membuat prosedur prediksinya dapat diamati (Gorunescu, 2011).

Decision tree banyak digunakan untuk menyelesaikan kasus penentuan keputusan seperti di bidang kedokteran (diagnosis penyakit pasien), ilmu computer (struktur data), psikologi (teori pengambilan keputusan) dan sebagainya.

Sedangkan Algoritma C4.5 diperkenalkan oleh Quinlan (1996) sebagai versi perbaikan dari ID3.Dalam ID3, induksi decision tree hanya bisa dilakukan pada fitur bertipe kategorikal (nominal atau ordinal), sedangkan tipe numeric (interval atau rasio) tidak dapat digunakan. Perbaikan yang membedakan algoritma C4.5 dari ID3 adalah dapat menangani fitur dengan tipe numerik, melakukan pemotongan (pruning), dan penurunan (deriving) rule set. Algoritma C4.5 juga menggunakan kriteria gain dalam menentukan fitur yang menjadi pemecah node pada pohon yang diinduksi.( Prasetyo Eko, 2014)

Algoritma C4.5 membuat pohon keputusan dari atas kebawah, dimana atribut paling atas merupakan akar, dan yang paling bawah dinamakan daun. Node adalah atribut yang mempunyai nilai gain tertinggi dari atribut-atribut yang ada. Untuk menghitung nilai gain suatu atribut digunakan rumus seperti yang tertera dalam persamaan berikut :

$$
\begin{array}{cll}
\operatorname{Gain}(S, A)= & \text { Entropy } & (S)-\left(\sum_{i=1}^{n} \frac{A i}{S} * \operatorname{Entropy}(A i)\right) \\
\text { Keterangan : } S \quad \text { Kasus } & \\
& A \quad: \text { Atribut } \\
n & : \text { Jumlah partisi atribut A } \\
& A i \quad: \text { Jumlah Kasus pada partisi ke -i } \\
& S \quad: \text { Jumlah Kasus }
\end{array}
$$

Sementara itu, untuk menghitung nilai Entropy dapat dilihat pada persamaan berikut ini :

$$
\begin{aligned}
& \operatorname{Entropy}(S)=\sum_{i=1}^{n}-p i * \log 2 p i \\
& \text { Keterangan : } S \quad \text { : Himpunan Kasus } \\
& n: \text { Jumlah Prtsi } S \\
& p i: \text { Proposi dari Sike } S
\end{aligned}
$$

\section{Rancangan Penelitian}

Dalam desain perancangan penelitian yang digunakan mengikuti langkah-langkah pelatihan dalam sistem pendukung keputusan. Diagram rancangan dalam penelitian ini di ilustrasikan pada gambar 1 . 


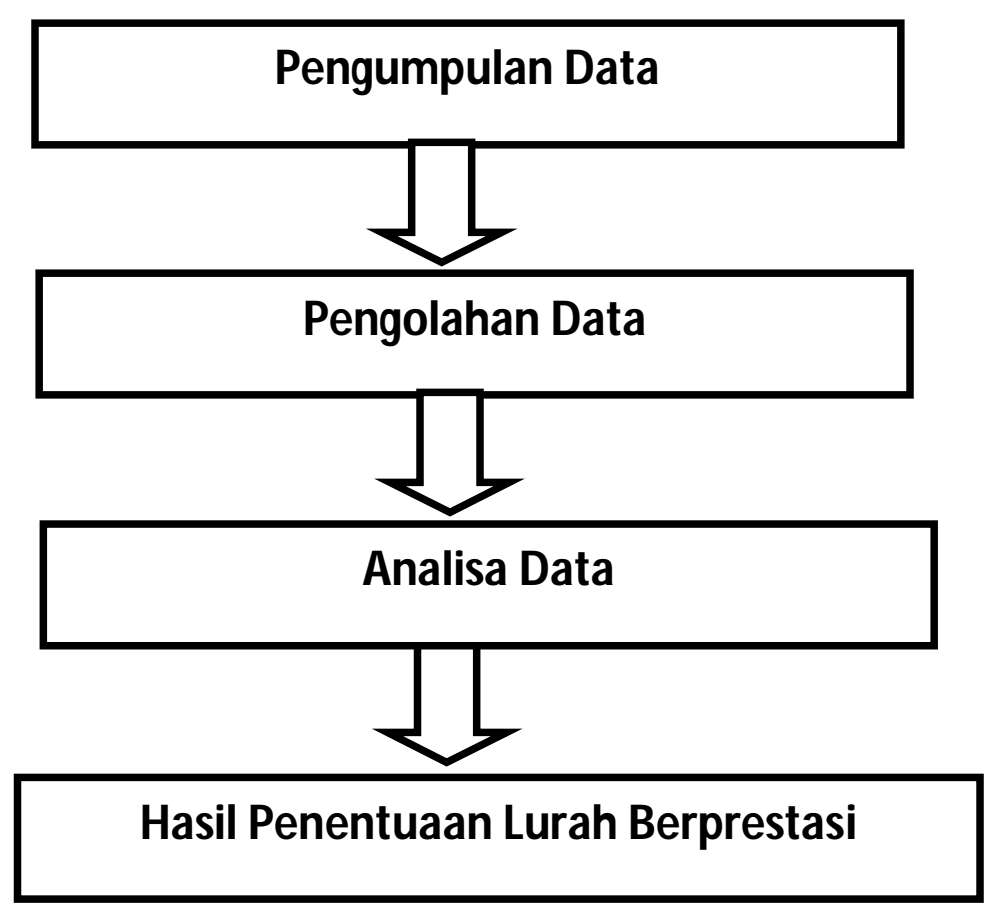

Gambar 1. Rancangan Penelitian

\section{Sumber Data}

Data merupakan bagian terpenting dalam penelitian ini, sumber yang diambil berasal dari Kecamatan Bogor Timur Kota Bogor. Data diperoleh langsung dari objek penelitian yaitu dari hasil wawancara, berupa data Lurah mengenai penilaian kinerja masing - masing Lurah untuk penentuan Lurah berprestasi yang ada di objek penelitian. Data ini disebut sebagai sumber data utama.

\section{Instrumen Penelitian}

Dalam langkah ini untuk melengkapi penelitian diperlukan instrument pendukung, adapun instrument tersebut dapat dilihat pada tabel 1.

Tabel 1 Instrumen Penelitian

\begin{tabular}{|c|c|c|c|}
\hline Variable & Indikator & Kriteria & Penjelasan \\
\hline $\begin{array}{l}\text { Penentuan } \\
\text { Lurah } \\
\text { Berprestasi Se- } \\
\text { Kecamatan } \\
\text { Bogor Timur }\end{array}$ & $\begin{array}{l}\text { a. Kuantitas } \\
\text { b. Kualitas } \\
\text { c. Waktu } \\
\text { d. Biaya }\end{array}$ & $\begin{array}{l}\text { Sasaran Kerja } \\
\text { Pegawai } \\
\text { (SKP) }\end{array}$ & $\begin{array}{l}\text { Penilaian dari Kriteria ini } \\
\text { dinilai berdasarkan kuantitas, } \\
\text { kualitas, waktu dan biaya } \\
\text { dimana proses perhitungan } \\
\text { sebesar } 30 \%\end{array}$ \\
\hline & $\begin{array}{l}\text { a. Integritas } \\
\text { b. Komitmen } \\
\text { c. Disiplin } \\
\text { d. Kerjasama } \\
\text { e. kepemimpinan }\end{array}$ & Prilaku kerja & $\begin{array}{l}\text { Penilaian pada prilaku kerja } \\
\text { dinilai berdasarkan } 5 \text { indikator } \\
\text { dimana nilai bobot penilaian } \\
\text { sebesar } 25 \%\end{array}$ \\
\hline & $\begin{array}{l}\text { Program unggulan } \\
\text { a. Pencapaian } \\
\text { program dalam } \\
\text { peraihan PBB }\end{array}$ & $\begin{array}{l}\text { Kreatifitas dan } \\
\text { Inovasi. }\end{array}$ & $\begin{array}{l}\text { Penilaian ini dilakukan } \\
\text { berdasarkan } \\
\text { program dan ide kreatifitas } \\
\text { dalam mengembangkan }\end{array}$ \\
\hline
\end{tabular}




\begin{tabular}{|c|c|c|c|}
\hline & $\begin{array}{l}\text { b. Memenangkan } \\
\text { berbagai lomba } \\
\text { di Tk.Kota } \\
\text { Provinsi contoh } \\
\text { P2WKSS } \\
\text { c. Angka } \\
\text { pengangguran } \\
\text { d. Pengentasan } \\
\text { kemiskinan }\end{array}$ & & $\begin{array}{l}\text { kelurahan dan memajukan } \\
\text { masyarakat. Bobot penilian ini } \\
\text { sebesar } 20 \%\end{array}$ \\
\hline & $\begin{array}{l}\text { a. Pelayanan } \\
\quad \text { Publik. } \\
\text { Pelayanan yang } \\
\text { baik dalam } \\
\text { menghadapi warga } \\
\text { masyarakat. }\end{array}$ & $\begin{array}{l}\text { Orientasi } \\
\text { Pelayanan }\end{array}$ & $\begin{array}{l}\text { Penilain ini dilakukan } \\
\text { berdasarkan } \\
\text { terhadap pelayanan } \\
\text { masyarakat,pendekatan } \\
\text { terhadap warga adanya } \\
\text { kontribusi dan timbal balik } \\
\text { antara Lurah dan warga } \\
\text { masyarakat. Bobot penilaian } \\
\text { ini sebesar } 15 \%\end{array}$ \\
\hline & $\begin{array}{lr}\text { Penilaian } & \text { dari } \\
\text { Lurah } & \text { se } \\
\text { Kecamatan } & \text { Bogor } \\
\text { Timur } & \end{array}$ & $\begin{array}{l}\text { Penilaian } \\
\text { Lurah }\end{array}$ & $\begin{array}{l}\text { Penilain Lurah dimaksud } \\
\text { adalah Lurah a dinilai oleh } \\
\text { lurah b, kemudian Lurah b } \\
\text { dinilai Lurah c, dan } \\
\text { seterusnya bobot penilaian } \\
\text { sebesar } 10 \%\end{array}$ \\
\hline
\end{tabular}

\section{Analisa Data}

Membuat matriks keputusan untuk menentukan alternatif berdasarkan kriteria, kemudian melakukan normalisasi matriks berdasarkan persamaan yang disesuaikan dengan jenis atribut sehingga diperoleh matriks ternormalisasi $R$.

Proses analisa pemilihan Lurah berprestasi se-Kecamtan Bogor Timur Kota Bogor menggunakan Simple Additive Weighting dari proses perangkingan yaitu penjumlahan dari perkalian matrik ternormalisasi $\mathrm{R}$ dengan vector bobot sehingga diperoleh nilai terbesar yang dipilih sebagai alternatif terbaik.

Dalam hasil dari perhitungan dengan metode yang digunakan,perlu adanya pengukuran hasil yang didapat dari metode yang digunakan. Maka peneliti menggunakan perhitungan akurasi yang bertujuan untuk mengetahui seberapa akurat metode yang digunakan. Dalam bukunya yang berjudul Data Mining, menurut Eko Prasetyo (2014 , p.257) sebuah sistem yang melakukan klasifikasi diharapkan dapat melakukan klasifikasi semua set data dengan benar. Akan tetapi tidak dapat dipungkiri bahwa kinerja suatu sistem tidak bisa bekerja $100 \%$ benar. Oleh karena itu, sebuah sistem klasifikasi juga harus diukur kinerjanya. Dengan mengetahui jumlah data yang diklasifikasikan secara benar maka dapat diketahui akurasi hasil prediksi. Untuk mengetahui akurasi digunakan formula sebagai berikut:

$$
\text { Akurasi }=\frac{\text { Jumlah yang diklasifikasi secara benar }}{\text { Total sampel testing yang diuji }}
$$

\section{Pembahasan}

\section{Analisa Kebutuhan Kriteria}

Dalam penentuan Lurah berprestasi menggunakan Metode Decision Tree diperlukan kriteria-kriteria dan nilai bobot untuk melakukan proses perhitungan guna mendapatkan alternatif terbaik yaitu Lurah Berprestasi se-Kecamatan Bogor Timur Kota Bogor. Kriteria 
tersebut didapat berdasarkan hasil wawancara pada tanggal 02 Oktober 2015 dengan bagian Kepegawaian Kecamatan Bogor Timur. Kriteria yang ditetapkan dalam penelitian ini terdiri dari 5 (Lima) kriteria yaitu :

Tabel 2. Kriteria Penentuan Lurah Berprestasi se-Kecamatan Bogor Timur

\begin{tabular}{|c|c|}
\hline Kriteria & Keterangan \\
\hline C1 & Sasaran Kerja Pegawai (SKP) \\
\hline C2 & Prilaku Kerja \\
\hline C3 & Kreatifitas dan Inovasi \\
\hline C4 & Orientasi Pelayanan \\
\hline C5 & Penilaian Lurah \\
\hline
\end{tabular}

Setelah kriteria diperoleh maka ditentukan rating kecocokan setiap alternatif pada setiap kriteria, dimana setiap alternatif pada setiap kriteria dinilai 1 sampai dengan 5 , yaitu :

Tabel 3. Nilai Rating Kecocokan dari setiap alternatif pada setiap kriteria

\begin{tabular}{|c|c|}
\hline Nilai & Keterangan \\
\hline 1 & Sangat Kurang \\
\hline 2 & Kurang \\
\hline 3 & Cukup \\
\hline 4 & Baik \\
\hline 5 & Sangat Baik \\
\hline
\end{tabular}

Karena setiap nilai yang diberikan pada setiap alternatif di setiap kriteria merupakan nilai kecocokan (nilai terbesar adalah nilai terbaik), maka semua kriteria yang diberikan diasumsikan sebagai kriteria keuntungan.

Dari hasil wawancara tanggal 02 Oktober 2015 di bagian kepegawaian Kecamatan Bogor Timur Kota Bogor, maka diperoleh Nilai Bobot Preferensi (W) dari masing-masing kriteria sebagai berikut :

Tabel 4. Nilai Bobot Preferensi Setiap Kriteria

\begin{tabular}{|c|c|c|}
\hline Kriteria & Keterangan & Bobot \\
\hline C1 & Sasaran Kerja Pegawai (SKP) & $30 \%$ \\
\hline C2 & Prilaku Kerja & $25 \%$ \\
\hline C3 & Kreatifitas dan Inovasi & $20 \%$ \\
\hline C4 & Orientasi Pelayanan & $15 \%$ \\
\hline C5 & Penilaian Lurah & $10 \%$ \\
\hline \multicolumn{2}{|c|}{} & $100 \%$ \\
\hline
\end{tabular}

\section{Analisa Kebutuhan Alternatif}

Pada tahap ini adalah melakukan pengumpulan data Lurah melalui wawancara dari bagian kepegawaian Kecamatan Bogor Timur, ada 6 (enam) Lurah yang akan dinilai sebagai Lurah berprestasi, berikut alternatif - alternatif Lurah berprestasi tersebut :

Tabel 5. Data Lurah se-Kecamatan Bogor Timur (Alternatif)

\begin{tabular}{|c|c|c|}
\hline No & Alternatif & Nama Lurah \\
\hline 1 & A1 & Lurah Baranangsiang \\
\hline 2 & A2 & Lurah Sukasari \\
\hline 3 & A3 & Lurah Katulampa \\
\hline 4 & A4 & Lurah Tajur \\
\hline
\end{tabular}




\begin{tabular}{|c|c|c|}
\hline 5 & A5 & Lurah Sindangsari \\
\hline 6 & A6 & Lurah Sindangrasa \\
\hline
\end{tabular}

\section{Hasil}

Dari hasil perangkingan diatas diperoleh nilai terbesar adalah $A 3$, sehingga $A 3$ adalah alternatif terpilih sebagai alternatif terbaik. Jadi dapat disimpulkan Lurah yang mendapat penghargaan sebagai Lurah Berprestasi se-Kecamatan Bogor Timur Kota Bogor yaitu Lurah Katulampa.

Selanjutnya analisis terhadap sistem lama dan sistem baru (metode Simple Additive Weighting) dapat dilakukan untuk mencari tingkat perbandingan sistem lama dengan sistem baru (metode Simple Additive Weighting). Maka diperoleh tingkat perbandingan sebagaimana ditunjukan pada tabel 6.

Tabel 6. Hasil Perangkingan Sistem Lama dan Sistem Baru (SAW)

\begin{tabular}{|l|l|l|l|l|}
\hline Alternatif & $\begin{array}{l}\text { Sebelum menggunakan } \\
\text { Metode SAW }\end{array}$ & Rangking & Alternatif & $\begin{array}{l}\text { Setelah menggunakan } \\
\text { Metode SAW }\end{array}$ \\
\hline A1 & Lurah Baranangsiang & 1 & A3 & Lurah Katulampa \\
\hline A3 & Lurah Katulampa & 2 & A6 & Lurah Sindangrasa \\
\hline A6 & Lurah Sindangrasa & 3 & A4 & Lurah Tajur \\
\hline A5 & Lurah Sindangsari & 4 & A1 & Lurah Baranangsiang \\
\hline A4 & Lurah Tajur & 5 & A5 & Lurah Sindangsari \\
\hline A2 & Lurah Sukasari & 6 & A2 & Lurah Sukasari \\
\hline
\end{tabular}

Berdasarkan tabel 6 diatas maka proses perangkingan sebelum menggunakan sistem metode SAW diperoleh dengan cara menjumlahkan hasil nilai dari setiap kriteria yang digunakan tanpa ada nilai presentase dari setiap kriteria. Namun setelah menggunakan metode SAW proses penilaiannya dilakukan dengan cara penjumlahan terbobot yaitu dilakukan proses normalisasi matriks keputusan ke suatu skala yang dapat diperbandingkan dengan semua rating alternatif yang ada. Kemudian pembuat keputusan menentukan bobot bagi setiap kriteria, kemudian skor total untuk alternatif diperoleh dengan menjumlahkan seluruh hasil perkalian antara rating dan bobot tiap kriteria untuk memperoleh alternatif terbaik yaitu alternatif Lurah berprestasi.

Dari alternatif yang telah diurutkan berdasarkan peringkat seperti pada tabel 15 maka dapat dilihat siapa yang berhak mendapatkan penghargaan sebagai Lurah berprestasi seKecamatan Bogor Timur Kota Bogor

Untuk membuktikan bahwa penerapan Metode Decision Tree memperoleh hasil yang lebih baik dan tepat dari pada metode yang digunakan sebelumnya (Metode Sistem Lama) maka dilakukan perbandingan hasil perhitungan antara data yang sudah terjadi dengan data yang sewajarnya dan data yang sudah terjadi dengan data hasil perhitungan metode Decision Tree.

Data yang sudah terjadi yaitu data yang diperoleh dari hasil perhitungan sistem lama yang sudah dilakukan oleh Camat Bogor Timur Kota Bogor. Data yang sewajarnya yaitu data yang 
diperoleh dengan cara mengurutkan nilai terbesar sampai nilai yang terkecil dari hasil nilai akhir setiap kriteria (berdasarkan

kriteria yang sudah ditentukan) dan Data dengan metode Decision Tree yaitu data yang diperoleh dari hasil perhitungan dengan menggunakan metode Decision Tree.

Berdasarkan tabel 4.14 diatas maka nilai perbandingan antara data yang sudah terjadi dengan data dengan metode Decision Tree yaitu sebanyak 5 alternatif yaitu Lurah Katulampa, Lurah Sindangrasa, Lurah Tajur, Lurah Baranangsiang dan Lurah Sindangsari.

Menurut Eko Prasetyo Untuk menunjukan Tingkat akurasi metode SAW digunakan rumus sebagai berikut :

$$
\begin{gathered}
\text { Akurasi }=\frac{\text { Jumlah yang diklasifikasi secara benar }}{\text { Total sampel testing yang diuji }} \\
\text { Akurasi }=\underline{5}=0,83 \\
6
\end{gathered}
$$

Dari perhitungan diatas diperoleh hasil akurasi adalah sebesar 0,83 atas sebesar $83 \%$ dimana angka 5 adalah jumlah data yang diklasifikasi secara benar dengan metode SAW dan angka 6 adalah total data yang diuji. Sehingga dapat disimpulkan bahwa hasil perhitungan dengan menggunakan metode Decision Tree lebih tepat dari pada sebelum menggunakan metode Decision Tree dalam penentuan Lurah berprestasi se-Kecamatan Bogor Timur Kota Bogor.

\section{Kesimpulan}

Berdasarkan tujuan penelitian yang telah dilakukan, maka dapat disimpulkan :

Dengan menggunakan metode Simple Additive Weighting (SAW) untuk optimalisasi penentuan Lurah berprestasi se-Kecamatan Bogor Timur Kota Bogor, maka didapatkan alternatif Lurah Berprestasi sesuai dengan kriteria yang ditetapkan oleh Kecamatan Bogor Timur yaitu Lurah Katulampa dengan nilai sebesar 0,95, Lurah Sindangrasa sebesar 0,93, Lurah Tajur sebesar 0,91, Lurah Baranangsiang sebesar 0,87, Lurah Sindangsari sebesar 0,86 dan Lurah Sukasari 0,80. Dari Uraian ditas dapat disimpulkan bahwa yang berhak mendapatkan penghargaan sebagai Lurah Berprestasi se-Kecamatan Bogor Timur Kota Bogor adalah Lurah Katulampa dengan nilai sebesai 0,95.

\section{Saran}

Berdasarkan kesimpulan yang diuraikan sebelumnya, peneliti memberikan saran yang dapat dijadikan bahan pertimbangan untuk pengambilan keputusan dalam optimalisasi penentuan Lurah Berprestasi se-Kecamatan Bogor Timur Kota Bogor yaitu sebagai berikut:

a. Penentuan kriteria dan bobot dari kriteria-kriteria sangat berpengaruh terhadap hasil akhir sehingga kriteria-kriteria tersebut harus dikaji secara seksama agar memperoleh hasil yang maksimal dalam memperoleh hasil dalam penentuan Lurah berprestasi seKecamatan Bogor Timur Kota Bogor. 
b. Dalam menentukan Lurah berprestasi dapat dilakukan penambahan jumlah kriteria

c. Dalam proses penilaian agar dihitung sesuai dengan kriteria yang sudah ditentukan sehingga hasil yang didapat dapat lebih optimal.

d. Membuat sistem atau aplikasi untuk dapat mempermudah dalam membuktikan metode Simple Additive Weighting (SAW) dalam penentuan Lurah berprestasi se-Kecamatan Bogor Timur Kota Bogor.

\section{Daftar Pustaka}

Bambang Sulistiyono (2013) Pemilihan Karyawan Terbaik di STMIK Pringsewu Dengan Menggunakan Metode SAW.

Denay Islam Sabanaya (2014), Sistem Pendukung Keputusan Penentuan Karyawan Terbaik Menggunakan Metode SAW Pada PT.Berkah Cahaya Muria Kudus.

Eko Prasetyo (2014) Data Mining Mengolah Data Menjadi Informasi Menggunanakan Matlab Yogyakarta.

Fajar Ari Setyanto (2014) Pengembangan aplikasi Sistem Pendukung Keputusan Pemilihan Karyawan Berprestasi dengan metode SAW Studi Kasus di PT.Horrison \& Gil-Jawa Semarang.

Hendry Mandala Putra (2013), Sistem Pendukung Keputusan Pemilihan Karyawan Berprestasi di Pertamina Pengapon Semarang

Kusumadewi, Sri. 2006. Fuzzy Multi-Attribute Decision Making (Fuzzy MADM). Graha IImu, Yogjakarta.

Oky Setiawan (2014), Sistem Pendukung Keputusan Pegawai Berprestasi Pada BPR RAM Menggunakan metode Simple Additive Weighting

Peraturan Daerah Provinsi Jawa Barat tentang Gelar Kehormatan, Warga Kehormatan dan Penghargaan Daerah (lembaran Daerah Provinsi Jawa Barat Tahun 2012 Nomor 6 Seri E Tambahan Lembaran Daerah Provinsi Jawa Barat Nomor 120.

Peraturan Gubernur Jawa Barat No. 19 Tahun 2014 tentang Pemberian Penghargaan Pegawai Negeri Sipil Teladan di Jawa Barat.

Peraturan Pemeritah No. 10 Tahun 1979 tentang Penilaian pelaksanaan pekerjaan pegawai Negeri Sipil.

Yohana Dewi Lulu W, Rani Maya Sari, Heni Rachmawati (2010), Sistem Pendukung Keputusan Penentuan Karyawan Terbaik menggunakan metode Simple Additive Wighting Studi Kasus PT.Pertamina RU II Dumay 